\title{
Bioactivity of Endophytes from the Brazilian Tropical Savannah
}

\author{
Andréa Cristina Bogas ${ }^{1,2 *}$, Flavia Luana Torres ${ }^{2}$, Cristina Paiva de \\ Sousa $^{1,2}$ and Paulo Teixeira Lacava ${ }^{1,2}$ \\ ${ }^{1}$ Department of Morphology and Pathology, Center for Biological and Health \\ Sciences, Federal University of São Carlos, Brazil \\ ${ }^{2}$ Post-graduation Program of Biotechnology, Federal University of São Carlos, \\ Brazil \\ *Corresponding Author: Andréa Cristina Bogas, Department of Morphology \\ and Pathology, Center for Biological and Health Sciences, Federal University of \\ São Carlos, Brazil.
}

Received: July 01, 2020

Published: August 18, 2020

(C) All rights are reserved by Andréa Cristina

Bogas., et al.

\begin{abstract}
The Brazilian tropical savannah is a mosaic biome, the second largest in the Brazilian territory and the most biodiverse tropical savannah in the world. Endophytes and host plants have a symbiotic relationship, in which both are beneficial. The host plant provides protection to the endophytes, which, in turn, increase the fitness of the plant by inducing resistance to pathogens due to niche competition and/or synthesizing antibiotics, lytic enzymes and siderophores. Although initial studies on endophytes were directed to those living in symbiosis with temperate plants, in recent years, many reports describing the isolation of endophytic bacteria and fungi from tropical plants have been published. Secondary metabolites produced by endophytes are a promising source of bioactivity. The biochemical versatility and diversity of these microorganisms suggest that there are many unknown active compounds. Another important goal is the agronomic potential of endophytic fungi from tropical savannah. Bioprospecting studies have reported the potential of endophytes against a large number of phytopathogens responsible for large losses in economically important tropical crops. Thus far, the main method for controlling plant diseases is the application of chemicals. Nevertheless, chemicals cause toxic effects to humans, animals and the environment. Therefore, endophytic microorganisms have been considered an alternative for the control of phytopathogens and consequent augmented crop production. The lack of studies related to endophytes isolated from tropical environments enhances their importance. This review focuses on the potential activities produced by endophytes isolated from medicinal plants and their industrial, pharmaceutical and agronomic applications.
\end{abstract}

Keywords: Endophytic Microorganisms; Cerrado; Bioactive Compounds; Antimicrobial; Biocontrol; Plant Growth Promotion

The Brazilian tropical savannah, known as the Cerrado, is one of the richest habitats of the world with regard to diversity in fauna and flora [1]. The number of endemic plants is high, and it is estimated that more than 4400 species of higher plants can be found in this savannah [2-4]. The Cerrado ecosystem is characterized by seasonal weather with an annual precipitation that varies between 1200 and $1800 \mathrm{~mm}$ and a dry season that occurs during 5 - 6 months a year and comprises a rich and characteristic flora [5], which makes it one of the 25 most important terrestrial biodiversity hotspots on the planet [4]. 
Endophytes are microorganisms that inhabit the interior of plant tissues without harming their hosts. This definition includes internal colonists with apparently neutral behavior, symbionts and bacteria that migrate between the surface and the inside of the plant during their endophytic phase [6]. The term endophyte is applied to microorganisms, frequently bacteria and fungi, that colonize living plant tissues for all or part of their life cycle but cause no apparent infection or symptoms of disease [7].

Significant attention has been given to the exploration of new bioactive compounds that can be synthesized by endophytic microorganisms [8]. It provides an alternative to the exploitation of plants, helping in the flora diversity preservation, which is become increasingly scarce in the world [9] as well as reducing the market value of these biomolecules [10]. The broad spectrum of biological activity of endophytes isolates allow, among other things, the exploration of substances with potential antimicrobial, and production of enzymes, which can be obtained on a large scale through fermentation and present a great potential for industrial applications $[11,12]$.

Plants native to the Brazilian savannah are commonly used to treat skin diseases, ulcers, anemia, diabetes, malaria, inflammatory reactions, and hepatic diseases, and this medicinal flora has been used as folk medicine by different people as an alternative to high-priced pharmaceutical drugs $[13,14]$. Several endophytes from the Brazilian savannah have been reported for their microbial activities, such as antibiotic capability against gram-positive and gram-negative bacteria, antifungal activity, antibiotic resistance properties, enzyme production, antitumor activity, and antiLeishmania activity [15-18].

This review comprises the concept and applications of endophytic microorganism and their relationship with medicinal plants. The medicinal utilization of these bioactive compounds produced by bacteria and fungi as well as agronomic potential for crop improvement have been explored.

\section{Tropical savannah trees}

The Brazilian Cerrado is a biome composed of savannah and forest ecosystems that cover approximately 2 million $\mathrm{km}^{2}$, representing ca. $22 \%$ of the land surface of Brazil, plus small areas in eastern Bolivia and northwestern Paraguay [19].
Some research has shown that the Cerrado ecosystems can harbor a large and diverse population of plant-associated fungi with many new fungal taxa [20]. Although interest in microbial biodiversity in the Brazilian Cerrado has increased, the diversity, taxonomic composition, host affinity and biotechnological potential of fungi from this ecosystem remain unclear.

The Brazilian tropical savannah (Cerrado) is the second largest biome in Brazilian territory, with approximately 2,036,448 $\mathrm{km}^{2}$, an area that is equivalent to almost a quarter $(23,52 \%)$ of the national territory [21], and more than 6,000 vascular plant species [22]. This diversity results from the adverse environmental conditions caused by fire, leading to specific adaptations and different phytophysiognomies that characterize the biome [23,24].

\section{Bioactive molecules from tropical savannah endophytes}

The Brazilian tropical savannah occupies a large area in Brazil and includes a high variety of plant species [1]. This diversity is an important source of endophytic microorganisms consisting mainly of bacteria and fungi that inhabit the interior of plants [25]. Endophytes represent an extensive source of promising natural products because large-scale cultivation may be able to produce an enormous amount of secondary metabolites while keeping costs reasonable [26,27]. Evidence suggests a close microbial-plant relationship that functions symbiotically $[28,29]$.

Drug-resistant microorganisms have also generated attention in recent decades, and studies estimate that over 700,000 million deaths worldwide are caused by these microorganisms [30]. Considering studies developed by Allen., et al. [31], microorganisms can carry genes encoding resistance to the antibiotics they produce. Many important antibiotics in the pharmaceutical industry have been derived from microbial metabolites [32,33]. The biochemical versatility and diversity of these microorganisms suggest that there are many still unknown active compounds [26]. In this way, several studies have reported the potential of endophytic microorganisms obtained from the Brazilian tropical savannah in the production of metabolites with the potential to control human pathogens [16-18,25].

Assis [34] described endophytes associated with Caryocar brasiliense, a plant species native to the Brazilian tropical savannah [35]. Although C. brasiliense is commonly used in folk medicine 
[36], there are only a few studies about its endophytic community and the production of secondary metabolites from this host plant [25,34]. According with Assis [34], forty-two endophytic microorganisms were isolated from $C$. brasiliense and one was identified as an actinobacteria belonging to the genus Streptomyces. In preliminary tests evaluating antimicrobial activity, six isolates showed activity against Staphylococcus aureus and one isolate, Actinobacteria, showed activity against Candida albicans and was selected for subsequent tests. Analysis of the growth kinetics of Streptomyces spp. demonstrated that the production of bioactive substances against $C$. albicans started at 40 hours. The bioactivity evaluation of the crude extract produced during coculture with potentially pathogenic microorganisms demonstrated a 50\% increase in inhibition of $C$. albicans and promoted inhibition of $S$. aureus, which had not been reported in axenic culture. The microdilution assay evaluated the bioactivity of lyophilized crude extract against $C$. albicans, which demonstrated an inhibition rate higher than $90 \%$ at a concentration of $10 \mathrm{mg} \cdot \mathrm{mL}^{-1}$ and $56 \%$ at $2 \mathrm{mg} \cdot \mathrm{mL}^{-1}$.

Ruela [37] examined the biotechnological potential of Bacillus pumilus, isolated from Tabebuia rosea alba, a Brazilian tropical savannah tree in São Paulo state, Brazil, and its metabolites. Based on this, the author reported that the B. pumilus strain demonstrated inhibitory activity against Escherichia coli and Staphylococcus aureus and antifungal activity against Candida albicans. The evaluation of the enzymatic activity showed positive results for lipase and esterase production. Satisfactory results were also observed for the performance of B. pumilus as a biological agent, which was able to inhibit the growth of 7 of the 16 phytopathogenic fungi tested. Interesting and promising results were observed regarding the antileishmanicidal and antitumor action of the extract from the B. pumilus strain.

Neris., et al. [18] worked with a total lyophilized extract (TLE) of Paenibacillus polymyxa RNC-D, which was isolated from Prunus spp. leaves that were collected from the Brazilian tropical savannah in São Carlos, SP, Brazil [25]. P. polymyxa strains are known for their capacity to segregate a large number of extracellular enzymes and bioactive substances [38,39]. The TLE of P. polymyxa RNC-D was tested in cell viability assays for cytotoxicity and cytokine production in fibroblast (BALB/3T3) and macrophage (J774A.1) cell lineages. A 50\% mortality rate of fibroblasts (BALB/3T3) was observed in the $1.171-0.161 \mathrm{mg} / \mathrm{mL}$ and $0.956-0.112 \mathrm{mg} / \mathrm{mL}$ doses after 48 and 72 hours, respectively, as well as a $50 \%$ mortality rate of macrophage cells (J774A.1) in the $0.994-0.170 \mathrm{mg} / \mathrm{mL}$ and $0.945-0.280 \mathrm{mg} / \mathrm{mL}$ doses after 48 and 72 hours, respectively. At $\approx 1 \mathrm{mg} / \mathrm{mL}$, the TLE significantly affected the growth kinetics at all the measured periods. At $\approx 1 \mathrm{mg} / \mathrm{mL}$, the extract induced apoptosis and necrosis in both tested lineages in 24 hours. Treatment with $\approx 1$ $\mathrm{mg} / \mathrm{mL}$ led to the production of TNF- $\alpha$ and IFN- $\gamma$ cytokines in 24 hours. IL-12 and IL-10 began to be detected after treatment with $0.1 \mathrm{mg} / \mathrm{mL}$. However, with the $0.5 \mathrm{mg} / \mathrm{mL}$ dose, a significant reduction in IL-10 was observed in 24 hours. These data suggest that the TLE of $P$. polymyxa RNC-D modulated the production of cytokines with different patterns of immune response in a dose-dependent manner.

Piza., et al. [17] isolated endophytic actinomycetes from the endemic medicinal plant Miconia albicans (Sw.) Triana (Melastomataceae) collected in the Brazilian tropical savannah and evaluated the action of secondary metabolites on human pathogens. One isolate identified as Amycolatopsis orientalis inhibited the growth of Staphylococcus aureus (ATCC 29213), Enterococcus faecalis (ATCC 29212), Candida albicans (ATCC 10231) and Shigella sonnei (ATCC 1578). The authors suggested that these findings can contribute to the discovery and characterization of new antimicrobial compounds with possible medical and/or industrial applications.

Serrano., et al. [16] reported the optimization of culture conditions for the production of antimicrobial metabolites by the endophytic bacterium Paenibacillus polymyxa RNC-D, isolated from leaves of Prunus spp., a Brazilian tropical savannah plant [25], against Escherichia coli ATCC 25922 This study demonstrated an important step in the development of strategies to elevate the production of antimicrobial molecules by this endophytic bacteria to control human pathogens.

Vaz., et al. [19] characterized the endophytic fungal community associated with three plants from Brazilian tropical savannah and determined the ability of these fungi to produce antimicrobial metabolites. Fungal endophyte communities associated with leaves of Myrciaria floribunda, Alchornea castaneifolia, and Eugenia aff. bimarginata were examined, collected from Brazilian savannah ecosystems, and studied for their ability to produce antimicrobial activity. A total of 93 isolates of endophytic fungi were obtained and identified by sequencing of internal transcribed spacer (ITS) 
regions of the rRNA gene, which revealed the presence of 20 Ascomycota and three Basidiomycota taxa. The genus Colletotrichum is the most frequent endophyte associated with M. floribunda and A. castaneifolia. Mycosphaerella is the most frequent genus associated with E. aff. bimarginata. All fungal endophytic isolates were cultured, and the crude extracts were screened to examine the antimicrobial activities against pathogenic microorganisms. Thirtyeight fungal extracts presented antimicrobial activity against at least one of the different target microorganisms tested. E. donezkii and C. gloesporioides showed the best minimum inhibitory concentration (MIC) values, which were lower or similar to the MICs of known antibacterial and antifungal drugs. The results suggest that the plants of the Brazilian tropical savannah shelter a diverse endophytic fungal community, which includes bioactive taxa capable of producing promising antimicrobial metabolites.

According to Favoretto [15], twenty-six endophytic microorganisms were isolated from Butia capitata var capitata (Coquinho-do-cerrado), Solanum lycocarpum (Lobeira), Stryphnodendron polyphyllu (Barbatimão), Miconia albicans (Quaresmeira-white) and Aegiphila lhotzliana (Tamanqueira), which were collected on Brazilian tropical savannah at São Carlos, SP, Brazil. The isolates were characterized through macroscopic, physiological, biochemical and morph-dying characteristics, and these endophytic isolates were identified as Streptomyces. The antagonistic potential of the endophytic isolates was tested against Staphylococcus aureus ATCC 25923, Escherichia coli ATCC 25922, Serratia marcensis ITB 1475, Enterococcus faecalis ATCC 29212, Shigella sonnei ATCC 10231 and Candida albicans ATCC 10231. The endophytes isolated from B. capitata var capitata inhibited the growth of $S$. aureus $(13 \mathrm{~mm})$ and E. faecalis (11 $\mathrm{mm})$, and the endophytes isolated from M. albicans did not show bioactivity against the pathogens tested.

Working with endophytic actinomycetes, Ratti., et al. [25] demonstrated that the microorganisms isolated from Cassia leptophylla, a Brazilian tropical savannah tree in São Paulo state, Brazil, had no ability to inhibit a Staphylococcus coagulase-positive strain, while microorganisms isolated from Prunus spp. presented antibacterial activity when cultivated in peptone agar (PA) as well as in yeast extract agar (YA).

Among the diversity of trees in the Brazilian savannah, our research group has considered two species: Stryphnodendron adstringens (Mart.) Coville (Fabaceae) and Solanum lycocarpum
Saint-Hill (Solanaceae). S. adstringens (Mart.) is a small tree, with a height ranging from 2 to 8 meters, a tortuous trunk and rigid and rough bark popularly known in Brazil as Bartimão [40]. Similar to S. lycocarpum, $S$ adstringens trees have potential for medicinal applications. Its bark and fruit contain anti-inflammatory [41], antiviral [42] and antimicrobial properties [43]. S. lycocarpum is a hairy shrub or small much-branched tree approximately 4 meters tall and popularly known in Brazil as Lobeira because it is part of the diet of wolves $[44,45]$. It is a plant adapted to the savannah and can resist a low water input [46]. Furthermore, S. lycocarpum produces secondary metabolites that exhibit antioxidant, antibacterial, cytotoxic and inflammatory properties $[47,48]$.

Torres [49] reported the study of 66 endophytic fungi obtained from $S$. adstringens and S. lycocarpum St. Hill collected in Brazilian Tropical Savannah Reserve from the Federal University of São Carlos, SP, Brazil The endophytic strains were evaluated in vitro for their antagonistic potential against the phytopathogens Colletotrichum sp., Fusarium oxysporum and Lasiodiplodia subglobosa and for their ability to solubilize inorganic phosphate (Figure 1 and 2 ). The results showed that endophytic strains exhibited antagonistic activity against the phytopathogens tested. Additionally, we observed a potential to solubilize inorganic phosphate with a mean phosphate solubilization index, ranging from 1.46 to 1.93 and 1.19 to 2.61 by endophytic strains.

In similar work, Noriler., et al. [50] assessed the fungal community associated with Stryphnodendron adstringens leaves and petioles collected in the savannah area of Miranda, Mato Grosso do Sul State, Brazil. The authors verified the antimicrobial activity of crude extracts produced by the endophytes and suggested that Diaporthe cf. heveae LGMF 1631 may represent an alternative to be used in the biocontrol of the plant pathogens Phyllosticta citricarpa and Colletotrichum abscissum.

Faria., et al. [51] studied the endophytic fungal community associated with the roots of Anacardium othonianum Rizzini, popularly known as "caju-de-árvore-do-cerrado" (cashew tree of the Cerrado), collected in Goiás State, Brazil. A total of 67 fungal strains were obtained and identified by sequencing the internal transcribed spacer (ITS), which revealed the presence of twelve species. Clustering by similarity between the morphotypes of endophytic fungal species showed their division in Basidiomycota and Ascomycota 


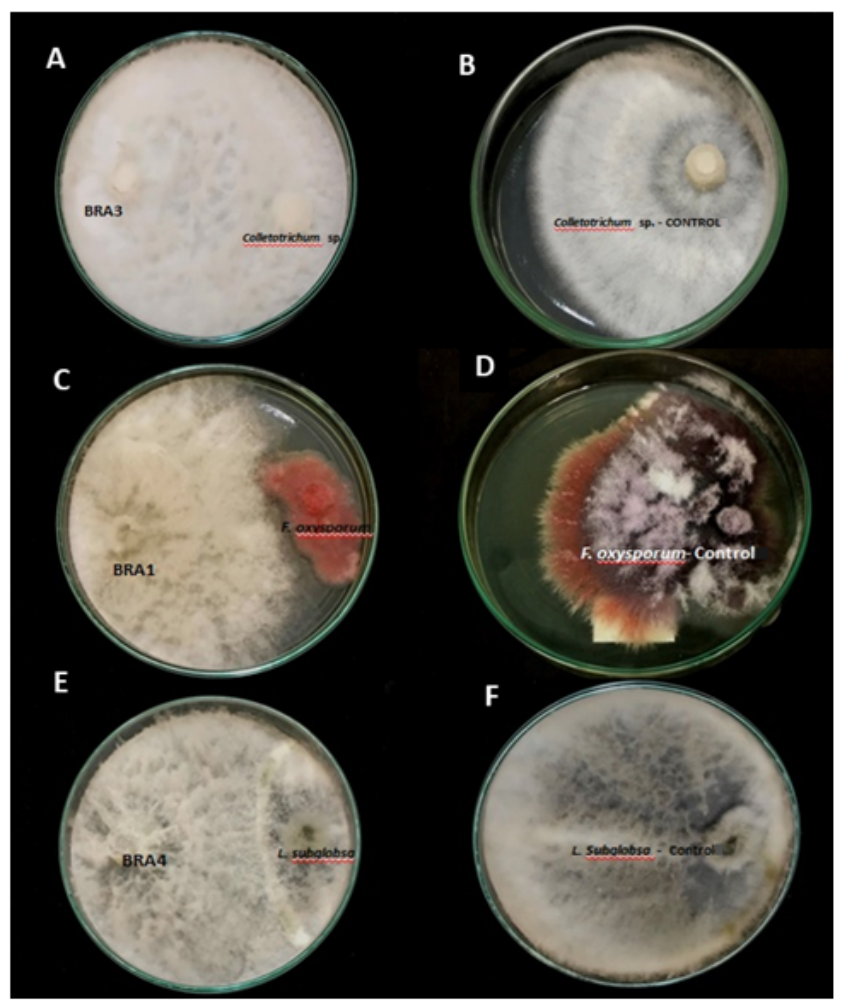

Figure 1: Dual culture plate assay between endophytic fungal isolates from Stryphnodendron adstringens (Mart.) Coville against the phytopathogen Colletotrichum sp., Fusarium oxysporum and Lasiodiplodia subglobosa grown in PDA. A) Interaction type CA1 for Pseudofusicoccum sp. BRA3 and Colletotrichum sp. B) Control Colletotrichum sp. C) Interaction type A for Neofusicoccum sp. BRA1 and Fusarium oxysporum. D)

Control Fusarium oxysporum. E) Interaction type A for Pseudofusicoccum sp. BRA4 and Lasiodiplodia subglobosa. F) Control Lasiodiplodia subglobosa .

phyla. In this same study, seven endophytic strains isolated from $A$. othonianum Rizzini showed potential for phosphate solubilization and indole acetic acid (IAA) synthesis, which are important mechanisms for plant growth promotion.

\section{Conclusion}

The data exhibited here suggest that Brazilian tropical savannah plants are a good source for endophytic microorganisms and

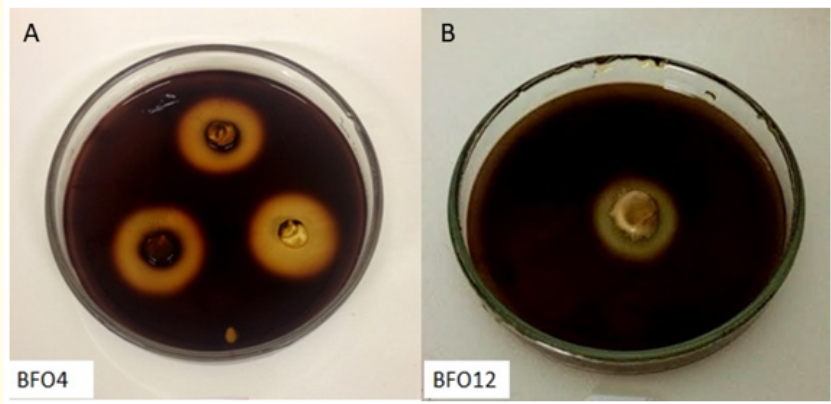

Figure 2: Pectate lyase (A) and poligalacturonasis (B) production by endophytes Neopestalotiopsis sp. BFO4 and

Schizophyllum sp. BF012, respectively, obtained from Stryphnodendron adstringens (Mart.) Coville.

emphasize the potential of natural compounds that can be used in the pharmaceutical industry and agricultural fields.

\section{Conflict of Interest}

All the authors declared that there are no conflicts of interest associated with this publication.

\section{Bibliography}

1. Batalha MA. "O cerrado não é um bioma”. Biota Neotropica 11.1 (2011): 21-24.

2. Ratter JA., et al. "The Brazilian Cerrado vegetation and threats to its biodiversity". Annals of Botany 80.3 (1997): 223-230.

3. Mendonça RC., et al. "Flora vascular do cerrado". In: Sano SM, Almeida SP (eds) Cerrado: ambiente e flora. Embrapa- CPAC (1998): 287-556.

4. Myers N., et al. "Biodiversity hotspots for conservation priorities". Nature 403 (2000): 853-858.

5. Adamoli J., et al. "Caracterização da região dos Cerrados". In: Goedert WJ (ed) Solos dos Cerrados: Tecnologias e Estratégias de Manejo. Embrapa and Nobel Press, São Paulo (1985): 33-74.

6. Hallmann J., et al. "Bacterial endophytes in agricultural crops". Canadian Journal of Microbiology 43.10 (1997): 895-914. 
7. Schulz B and Boyle C. "Microbial root endophytes". In: Sieber TN (ed) What are endophytes?. Springer, Berlin (2006): 1-13.

8. Strobel G. "The emergence of endophytic microbes and their biological promise". Journal of Fungi 4.2 (2018): 57.

9. Zheng Y., et al. "Diversity, distribution and biotechnological potential of endophytic fungi". Annals of Microbiology 66 (2016): 529-542.

10. Bibi SN., et al. "Fungal endophytes associated with mangroves Chemistry and biopharmaceutical potential". South Africa Journal of Botany (2020).

11. Marques NP., et al. "Cellulases and xylanases production by endophytic fungi by solid state fermentation using lignocellulosic substrates and enzymatic saccharification of pretreated sugarcane bagasse". Industrial Crops and Products 122 (2018): 66-75.

12. Yan L., et al. "Production of bioproducts by endophytic fungi: chemical ecology, biotechnological applications, bottlenecks, and solutions". Applied Microbiology and Biotechnology 102 (2018): 6279-6298.

13. Almeida SP., et al. "Cerrado espécies vegetais úteis". Embrapa, Planaltina, DF (1998): 464.

14. Pavan FR., et al. "In vitro anti- Mycobacterium tuberculosis activity of some Brazilian "Cerrado" plants". Revista Brasileira de Farmacognosia 19 (2009): 204-206.

15. Favoretto NB. "Produção de substâncias bioativas por microrganismos endofiticos isolados do cerrado de São Carlos". Dissertation, Universidade Federal de São Carlos, Brazil (2010).

16. Serrano NFG., et al. "Optimal glucose and inoculum concentrations for production of bioactive molecules by Paenibacillus polymyxa RNC-D". Chemical Papers 66.12 (2012): 1111-1117.

17. Piza ACMT., et al. "Endophytic actinomycetes from Miconia albicans (Sw.) Triana (Melastomataceae) and evaluation of its antimicrobial activity". Journal of Scientific Research and Reports 4.4 (2015): 281-291.
18. Neris DM., et al. "Cytotoxic effects and production of cytokines induced by the endophytic Paenibacillus polymyxa RNC-D in vitro". Current Pharmaceutical Biotechnoogy 18.9 (2017): 758768.

19. Vaz ABM., et al. "Diversity and antimicrobial activity of fungal endophyte communities associated with plants of Brazilian savanna ecosystems". African Journal of Microbiology Research 6 (2012): 3173-3185.

20. Furlanetto $\mathrm{C}$ and Dianese JC. "Some coelomycetes from Central Brazil”. Mycology Research 102.1 (1998): 19-29.

21. Rampelotto PH., et al. "Changes in diversity, abundance, and structure of soil bacterial communities in Brazilian Savanna under different land use systems". Microbiology Ecology 66 (2013): 593-607.

22. Felfili JM and Fagg CW. "Floristic composition, diversity and structure of the "Cerrado" sensu stricto on rocky soils in northern Goiás and southern Tocantins, Brazil". Revista Brasileira de Botânica 30 (2007): 375-385.

23. Pausas JG. "Homage to LM Coutinho: fire adaptations in Cerrado plants". International Journal of Wildland Fire 26.3 (2017): 249-251.

24. Pinheiro ES and Durigan G. "Diferenças florísticas e estruturais entre fitofisionomias do Cerrado em Assis, SP, Brasil". Revista Arvore 36.1 (2012): 181-193.

25. Ratti RP., et al. "Antagonistic properties of some microorganisms isolated from Brazilian tropical savannah plants against Staphylococcus coagulase-positive strain". Journal of Venomous Animals and Toxins including Tropical Diseases 14.2 (2008): 294-302.

26. Suryanarayanan TS., et al. "Fungal endophytes and bioprospecting". Fungal Biology Reviews 23.1-2 (2009): 9-19.

27. Debbab A. et al. "Bioactive secondary metabolites from endophytes and associated marine derived fungi". Fungal Diversity 49.1 (2011): 1-12. 
28. Strobel G.A., et al. "Natural products from 6 endophytic microorganisms". Journal of Natural Products 67.2 (2004): 257-268.

29. Gunatilaka AAL. "Natural products from plant-associated microorganisms: distribution, structural diversity, bioactivity and implications of their occurrence". Journal Natural Product 69.3 (2006): 509-526.

30. Bos J and Austin RH. "A bacterial antibiotic resistance accelerator and applications". Methods in Cell Biology 147 (2018): 41-57.

31. Allen HK., et al. "Call of the wild: antibiotic resistance genes in natural environments". Nature Reviews Microbiology 8 (2010): 251-259.

32. Owen NL and Hundley N. "Endophytes the chemical synthesizer inside plants". Science Progress 87 (2004): 79-99.

33. Huang B., et al. "Heterologous production of secondary metabolites as pharmaceuticals in Saccharomyces cerevisiae". Biotechnology Letters 30 (2008): 1121-1137.

34. Assis PCP. "Bactérias endofíticas isoladas de Caryocar brasiliense: atividade enzimática, antimicrobiana, leishmanicida e cocultura com microrganismos patogênicos". MS Thesis, Universidade Federal de São Carlos, Brazil (2018).

35. Araújo FD. "A review of Caryocar brasiliense (Caryocaraceae): an economically valuable of central Brazilian Cerrados". Economic Botany 49 (1995): 40-48.

36. Paula-Junior W., et al. "Leishmanicidal, antibacterial, and antioxidant activities of Caryocar brasiliensis leaves hydroethanolic extract". Revista Brasileira de Farmacognosia 16 (2006): 625-630.

37. Ruela AC. "Microbioma de Bacillus pumilus, endofítico associado à Tabebuia rosea alba do Cerrado e importância para a saúde: bioatividade e metabolômica”. Dissertation, Universidade Federal de São Carlos, Brazil (2018).

38. Lal S and Tabacchioni S. "Ecology and biotechnological potential of Paenibacillus polymyxa: A mini review". Indian Journal of Microbiology 49 (2009): 2-10.
39. Liang TW and Wang SL. "Recent advances in exopolysaccharides from Paenibacillus sp.: Production, isolation, structure, and bioactivities". Marine Drugs 13.4 (2015): 1847-1863.

40. Lorenzi H. “Árvores brasileiras: manual de identificação e cultivo de plantas arbóreas nativas do Brasil”. 2. ed. Plantarum, Nova Odessa (1998).

41. Lima JCS., et al. "Experimental evaluation of stem bark of Stryphnodendron adstringens (Mart.) Coville for anti-inflammatory activity". Phytotherapy Research 12 (1998): 218-220.

42. Felipe AMM., et al. "Antiviral effect of Guazuma ulmifolia and Stryphnodendron adstringens on poliovirus and bovine herpesvirus". Biological \& Pharmaceutical Bulletin 29.6 (2006): 1092-1095.

43. Almeida AC., et al. "Acute and chronic toxicity and antimicrobial activity of the extract of Stryphnodendron adstringens (Mart.) Coville". Pesquisa Veterinária Brasileira 37.8 (2017): 840-846.

44. Moura TM., et al. "Correlação entre floração, frutificação e variáveis ambientais em Solanum lycocarpum. A. St. Hil, Solanaceae". Bioscience Journal 26 (2010): 457-462.

45. Oliveira Junior EM., et al. "Alterações pós-colheita da "fruta-delobo" (Solanum lycocarpum St. Hil.) durante o amadurecimento: análises físico-químicas, químicas e enzimáticas". Revista Brasileira de Fruticultura 26.3 (2004): 410-413.

46. Elias SEM., et al. "Leaf anatomy in young plants of Solanum lycocarpum A. St-Hill. (Solanaceae)". Revista Brasileira de Botânica 26 (2003): 169-174.

47. Costa GAF., et al. "Antioxidant, antibacterial, cytotoxic, and anti-inflammatory potential of the leaves of Solanum lycocarpum A. St. Hil. (Solanaceae)". Evidence-Based Complementary and Alternative Medicine (2015).

48. Perez AC., et al. "Effect of Solanum lycocarpum St. Hill on various haematological parameters in diabetic rats". Journal of Ethnopharmacology 106.3 (2006): 442-444. 
49. Torres FL. "Isolamento, caracterização e potencial biotecnológico de fungos endofíticos associados às plantas de Cerrado". Dissertation, Universidade Federal de São Carlos, Brazil (2018).

50. Noriler AS., et al. "Bioprospecting and structure of fungal endophyte communities found in the Brazilian biomes, Pantanal, and Cerrado". Frontiers in Microbiology 9 (2018).

51. Faria PSA., et al. "Assessment of functional traits in the assemblage of endophytic fungi of Anacardium othonianum Rizzini". Pakistan Journal of Botany 48.3 (2016): 1241-1252.

\section{Assets from publication with us}

- Prompt Acknowledgement after receiving the article

- Thorough Double blinded peer review

- Rapid Publication

- Issue of Publication Certificate

- High visibility of your Published work

Website: www.actascientific.com/

Submit Article: www.actascientific.com/submission.php

Email us: editor@actascientific.com

Contact us: +919182824667 